\title{
PENDAMPINGAN PEMBUATAN MURAL SEBAGAI UPAYA PENINGKATAN PENDIDIKAN KARAKTER
}

\author{
Bagus Cahyanto ${ }^{1}$, Sitti Dian Rahayu ${ }^{2}$, Rhizma Nur Fitria ${ }^{2}$, Pedja Rifki Azizi ${ }^{2}$, Achmad \\ Syuro Al Arobi ${ }^{3}$, Masrukhin ${ }^{2}$, Syifa Mutmainah ${ }^{2}$, Novita Yulandra', Muhammad \\ Arrozak $^{3}$, Abd. Malik ${ }^{2}$ \\ ${ }^{1}$ Fakultas Agama Islam, Universitas Islam Malang \\ ${ }^{2}$ Fakultas Keguruan dan Ilmu Pendidikan, Universitas Islam Malang \\ ${ }^{3}$ Fakultas Ekonomi dan Bisnis, Universitas Islam Malang
}

Korespondensi email: baguscahyanto@unisma.ac.id

\begin{abstract}
ABSTRAK
Salah satu upaya yang dapat dilakukan untuk meningkatkan pendidikan karakter di sekolah adalah dengan seni mural. Selain dapat dijadikan sebagai media belajar, mural juga memperindah tampilan kawasan di daerah desa Jogomulyan untuk meningkatkan potensi lingkungan pariwisata. Metode yang dilakukan pada pendampingan dan pelatihan pembuatan mural ini adalah dengan metode ceramah, praktik dengan bimbingan, serta evaluasiTahap-tahap yang lakukan adalah memberi materi pendahuluan, tahap persiapan pembuatan mural, tahap melukis dan tahap finishing. Pelaksanaan kegiatan ini berjalan dengan baik sesuai dengan yang direncanakan, peserta antusias mengikuti kegiatan dan memberi respon yang positif. Kegiatan pengabdian masyarakat berupa pembuatan mural ini memberi keterampilan baru bagi masyarakat sekaligus menjadi media belajar untuk siswa mengembangkan pengetahuan pendidikan karakter.
\end{abstract}

Kata Kunci: mural; pendidikan; karakter; wisata.

\section{PENDAHULUAN}

Dalam usaha mendidik siswa yang berkarakter, terdapat delapan belas nilai-nilai pendidikan karakter yang mesti ditanamkan oleh seorang guru. Delapan belas pesan karakter tersebut adalah: religius, jujur, toleransi, disiplin, kerja keras, kreatif, mandiri, demokratis, rasa ingin tahu, semangat kebangsaan, cinta tanah air, menghargai prestasi, bersahabat/komunikatif, cinta damai, gemar membaca, peduli lingkungan, peduli sosial, tanggung jawab (Kurniawan, 2015) (Samrin, 2016). Pendidikan karakter sangat penting untuk pembentukan kepribadian siswa dan diharapkan mampu menjadi fondasi utama dalam membangun manusia Indonesia bertakwa dan siap bersaing di masa mendatang (Kurniasih et al., 2019).

Menurut beberapa penelitian terdahulu seperti yang dilakukan oleh Supardi U.S, (2012) dinyatakan bahwa pendidikan di Indonesia secara umum masih berorientasikan kepada hasil ujian. Oleh karena itu, sudah saatnya sistem pendidikan Indonesia direformasi karena belum mampu menjawab kebutuhan zaman (Diptoadi, 1999) (Nawawi, 2006). Merujuk kepada hasil penelitian dan pendapat tersebut, maka tentu perlu pembuktian secara empirik akibat dari kurang tepatnya arah pendidikan selama ini sehingga generasi sekarang cenderung rapuh, mudah emosi, dan kehilangan karakter sebagai generasi. Menanamkan nilai-nilai karakter terhadap siswa sebagaimana telah dirumuskan dalam 
Kurikulum 2013 merupakan langkah awal untuk memperbaiki tujuan pendidikan di Indonesia. Salah satu upaya yang dapat dilakukan adalah dengan mengadakan pembuatan mural edukasi (Hermuttaqien et al., 2019) (Muthoharoh, 2017).

Mural merupakan salah satu karya seni elemen ruang yang diwujudkan dalam bentuk lukisan ukuran besar mengisi dinding, langit-langit dan permukaan datar lainnya. Mural dapat digunakan sebagai media Pendidikan apabila konten isinya memuat nilai-nilai edukasi dan sarat akan pesan pesan moral (Thamrin \& Noviana, 2020). Mural juga dapat dijadikan sebagai petanda atau penanda identitas suatu tempat. (Ramadani \& Sabiruddin, 2018). Hal ini menunjukan bahwa mural dapat dijadikan sebagai media belajar untuk mengembangkan pendidikan karakter di sekolah sekaligus untuk mempercantik lingkungan sekitar sekolah (Sapentri, 2017).

Desa Jogomulyan merupakan salah satu desa di Kecamatan Tirtoyudo, Kabupaten Malang, Jawa Timur yang memiliki karakter daerah pariwisata. Selain itu, sistem penddikan di desa ini juga masih perlu dikembangkan terutama dalam hal meningkatkan penanaman pendidikan karakter di sekolah. Berdasarkan uraian diatas kegiatan pelatihan dan pendampingan dalam pembuatan mural sangat diperlukan agar masyarakat dapat mengembangkan potensi yang dimiliki pada desa sekaligus menanamkan pengetahuan pendidikan karakter terhadap generasi penerus.

\section{METODE}

Adapun metode yang akan dilakukan dalam kegiatan pengabdian masyarakat ini adalah sebagai berikut:

1. Metode Ceramah atau presentasi berkaitan dengan pengenalan konsep mural.

2. Metode Demonstrasi meliputi pengenalan langkah-langkah pembuatan mural serta berbagai tema desain yang dapat diterapkan.

3. Metode Praktik meliputi pendampingan pembuatan mural pada dinding yang telah ditentukan.

4. Metode Tanya jawab dan diskusi.

5. Metode evaluasi berupa umpan balik dari peserta pengabdian masyarakat.

Tahap pembuatan mural terbagi dalam beberapa langkah, yaitu sebagai berikut:

1. Tahap Persiapan

a. Menentukan tema (konsep) lukisan yang akan dibuat di dinding.

b. Membuat gambar (sketsa desain) sesuai dengan tema yang ditentukan dan ukuran bidang dinding yang akan dilukis.

c. Membersihkan dan mengam- plas dinding, hal ini dilakukan untuk memperkecil pori-pori dinding sehingga cat mudah menyerap. Dinding yang akan dilukis harus benar-benar bersih dari debu atau kotoran lain yang akan mengganggu tampilan mural. Jika ada dinding yang lubang maka harus ditambal terlebih dahulu.

d. Setelah seluruh dinding bersih, lapisi dinding dengan warna dasar. Tujuannya adalah untuk memperkuat daya lekat cat berikutnya.

2. Tahap Melukis

a. Tahap selanjutnya adalah melukis, dimulai dengan membuat pola gambar di dinding sesuai dengan sketsa desain yang sudah dibuat sebelumnya dengan menggunakan pensil/kapur tulis, untuk menghindari kesalahan sehingga mudah diperbaiki.

b. Batasi bidang dinding dengan plester/lakban kertas agar lukisan rapi dan mencegah cipratan cat. 
c. Mulai sapukan cat tembok secara bertahap, mengikut desain yang sudah dibuat. Selesaikan lukisan pada bagian background lebih dulu, kerjakan objek depan

3. Tahap Finishing (forward) di proses akhir (finishing).

Tahap akhir dari pembuatan mural ini adalah melapisi hasil gambar/lukisan dengan finishing vernis jenis doff agar tidak mengkilap saat terkena sinar lampu pada malam hari

\section{HASIL DAN PEMBAHASAN}

Program Pengabdian Masyarakat ini dibuat untuk memberikan pelatihan dan pendampingan pembuatan mural sebagai upaya meningkatkan kesadaran masayarakat terhadap pengembangan daerah pariwisita dan meningkatkan pengetahuan mengenai pendidikan karakter di desa Jogomulyan. Kegiatan pendampingan pembuatan mural ini diawali dengan pemberian materi mengenai pengetahuan umum tentang seni mural dan potensinya, serta fungsinya sebagai unsur estetika memperindah bangunan dan kawasan. Selain itu peserta juga diberi motivasi untuk mempelajari pembuatan mural dan manfaat apa yang didapat dari kegiatan ini. Pemahaman peserta dapat diukur dengan proses tanya jawab. Setelah metode ceramah perkenalan teori maka dilanjutkan dengan memperkenal alat dan bahan apa saja yang akan digunakan pada kegiatan ini.

Setelah itu dilanjutkan dengan pemberian penjelasan sekaligus mencontohkan proses pembuatan mural pada dinding yang telah ditentukan, dengan metode demonstrasi. Pelaksanaan kegiatan pendampingan pembuatan mural ini terdiri dari beberapa tahap, yaitu sebagai berikut:

\section{Tahap Persiapan Pembuatan Mural}

Pada tahap persiapan ini tim pelaksana menentukan tema (konsep) lukisan yang akan dibuat di dinding. Tema lukisan dibuat sesuai fungsi bangunan sebagai sekolah yaitu dengan gambar-gambar yang beunsur edukasi untuk meningkatkan pendidikan karakter. Tahap berikutnya yaitu membersihkan dan mengamplas dinding yang akan digambar, hal ini dilakukan untuk memperkecil pori- pori dinding sehingga cat mudah menyerap. Dinding yang akan dilukis harus benar-benar bersih dari debu dan kotoran lain yang akan mengganggu tampilan mural. Setelah seluruh dinding bersih, dinding dilapisi dengan cat warna dasar. Untuk memperkuat daya lekat cat berikutnya. Pemilihan warna dasar disesuaikan dengan konsep lukisan yang sudah dibuat.

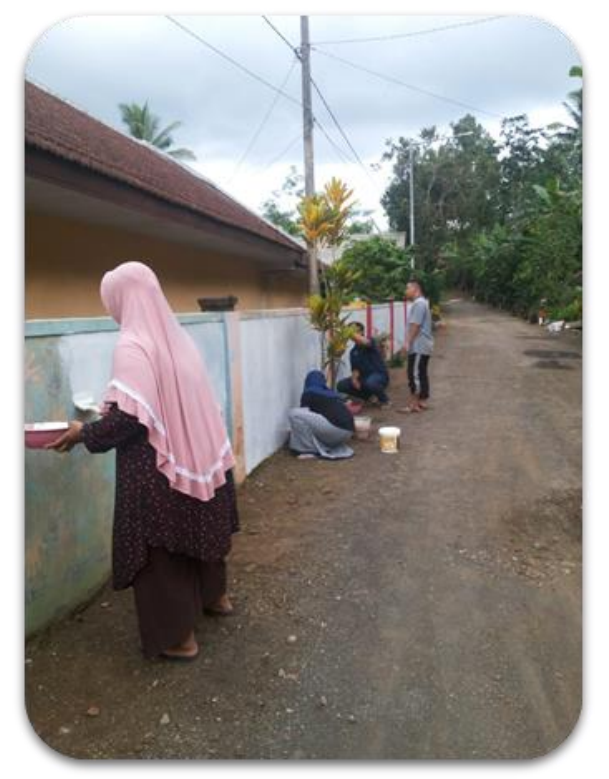

Gambar 1. Pengecatan dengan warna dasar 


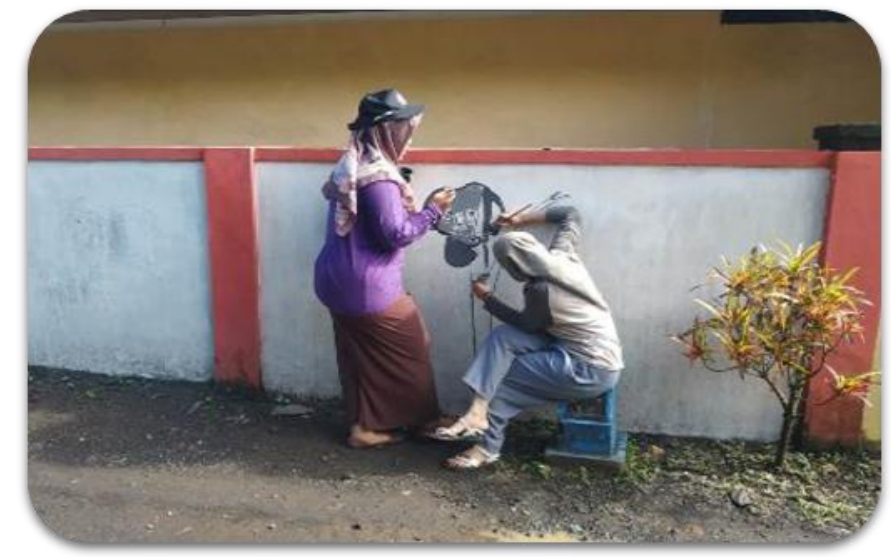

Gambar 2. Pengecatan dengan warna dasar

\section{Tahap Melukis Dinding}

Tahap berikutnya adalah membuat gambar di dinding. Peserta dibantu mahasiswa membuat pola gambar di dinding, sesuai dengan tema yang sudah dibuat sebelumnya menggunakan pensil dan kapur tulis. Setelah penggambaran pola selesai, selanjutnya mulai menyapukan cat tembok, secara bertahap, sesuai dengan gambar dan warna yang sudah dibuat. Membuat lukisan mural dimulai dari bagian background terlebih dulu, setelah itu dilanjutkan dengan objek depannya (forward).

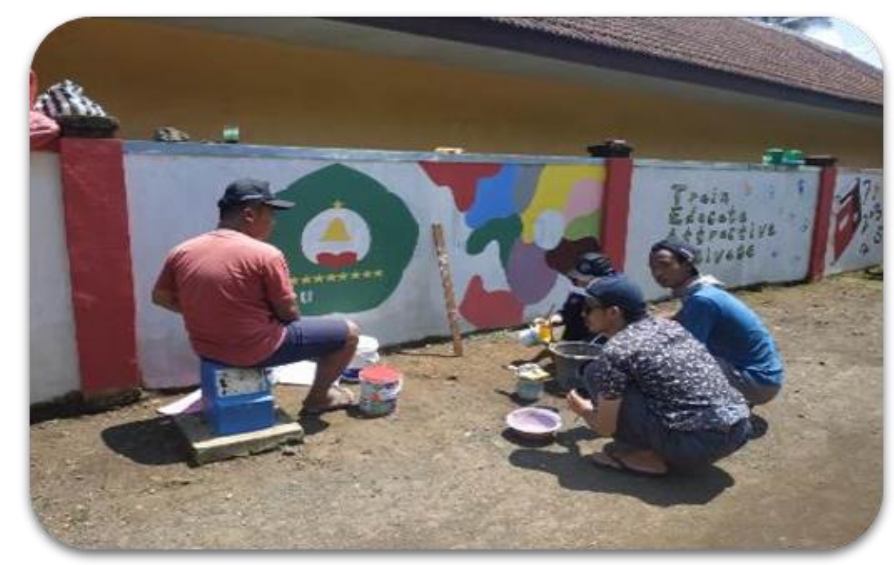

Gambar 3. Proses pengecatan gambar

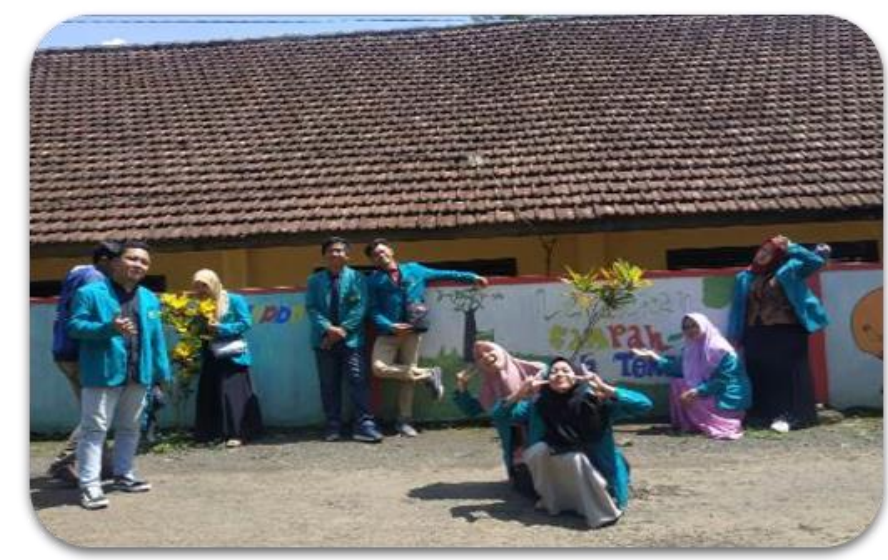

Gambar 4. Finishing mural edukasi di sekolah 
Pembuatan mural ini nantinya dapat diterapkan peserta pada dinding lainnya baik eksterior maupun interior dengan tema gambar yang berbeda sesuai keinginan. Mural yang dihasilkan pada kegiatan pengabdian masyarakat ini terlihat sedikit banyak dapat memperbaiki kualitas visual desa Jogomulyan. Umpan balik peserta dilakukan sebagai evaluasi pelaksanaan kegiatan pengabdian masyarakat pembuatan mural ini. Peserta diberikan kuesioner tertulis pada akhir kegiatan. Kuesioner berisi 5 pertanyaan pilihan ganda dan 1 pertanyaan uraian.

Dari pertanyaan pilihan ganda yang diberikan diperoleh hasil sebagian peserta belum pernah mendapat pelatihan pembuatan mural, sehingga mereka sangat tertarik dan antusias dalam mengikuti kegiatan ini. Dari pertanyaan uraian yang diberikan mengenai kritik dan saran terhadap pelaksanaan kegiatan pembuatan mural ini, sebagian besar peserta menilai positif kegiatan ini dan berharap pelatihan - pelatihan lain dapat diberikan lagi di desa Jogomulyan sehingga masayarakat mendapat banyak keterampilan untuk mengembangkan potensi wilayah wisata.

Pendampingan pembuatan mural sebagai pengetahuan yang baru dan juga bekal keterampilan dimasa yang akan datang. Kemudian, pembuatan mural dapat digunakan sebagai alternatif media penyaluran aspirasi karena tampilannya yang menarik dan komunikatif, sehingga dapat menyampaikan pesan yang terkandung dalam mural. Selain itu mural bisa mempengaruhi komponen-komponen sikap sosial individu antara lain: komponen kognitif, komponen afektif, dan komponen psikomotorik.

Keberadaan gambar-gambar dan warna juga dapat memperkuat karakter sebuah kawasan. Mural yang selama ini dianggap sebagai coretan kreativitas anak muda belaka ternyata memiliki sisi inovatif lain yang dapat dikembangkan secara maksimal sehingga mural tidak hanya terlihat dari sisi visualnya saja namun juga memiliki makna didalamnya.

Sejauh pendampingan pembuatan mural tidak ada kendala yang spesifik, semua berjalan dengan lancar dan teratur, hanya saja dalam proses pelukisan dinding ada beberapa kendala yaitu, cuaca yang kurang mendukung seperti turunnya hujan sehingga mengakibatkan jadwal yang ditunda-tunda dalam tahap pelukisan.

\section{KESIMPULAN}

Pengabdian masyarakat berupa pembuatan mural di desa Jogomulyan ini terlaksana dengan baik sesuai dengan yang direncanakan. Dari hasil evaluasi berupa kuesioner yang diberikan pada peserta diperoleh kesimpulan bahwa kegiatan pengabdian masyarakat ini memperoleh tanggapan positif dari masyarakat juga pihak sekolah. Dengan adanya mural ini kawasan SD Negeri 01 Jogomulayan terlihat lebih indah dan ceria, sehingga memberi dampak positif pada aspek pengembangan wisata. Selain itu, mural ini juga dapat dijadikan sebagai media belajar dalam mengembangkan pendidikan karakter di sekolah.

\section{DAFTAR RUJUKAN}

Diptoadi, V. L. (1999). Reformasi Pendidikan di Indonesia Menghadapi Tantangan Abad 21. Jurnal Ilmu Pendidikan, 6(3), 161-175. https://doi.org/10.17977/jip.v6i3.2333

Hermuttaqien, B. P. F., Sata, H. R., \& Wadu, L. B. (2019). Jurnal Inspirasi Pendidikan. Jurnal $\begin{array}{lll}\text { Inspirasi Pendidikan, 9(1), 39-44. } & \text {. }\end{array}$ http://ejournal.unikama.ac.id/index.php/jrnspirasi/article/view/3011

Kurniasih, Rahmati, N. A., Umamah, A., \& Widowati, D. R. (2019). English Conversation Class (ECC) Untuk Menciptakan English Environment Di SMA Islam Nusantara (SMAINUS). Jurnal Inovasi Hasil Pengabdian Masyarakat (JIPEMAS), 2(2), 161. 
https://doi.org/10.33474/jipemas.v2i2.2571

Kurniawan, M. I. (2015). Mendidik Untuk Membentuk Karakter Siswa Sekolah Dasar: Studi Analisis Tugas Guru Dalam Mendidik Siswa Berkarakter Pribadi Yang Baik. PEDAGOGIA: Jurnal Pendidikan, 121. https://doi.org/10.21070/pedagogia.v4i2.14

Muthoharoh. (2017). PROBLEM DAN SOLUSI IMPLEMENTASI KURIKULUM 2013 MATA PELAJARAN PENDIDIKAN AGAMA ISLAM DI MI KOTA SEMARANG (Studi Kasus di MI Darul Ulum Wates Ngaliyan dan MIN Sumurrejo, Gunungpati) [Universitas Islam Negeri Walisongo Semarang]. http://eprints.walisongo.ac.id/8407/1/1500118034_Tesis.pdf

Nawawi, N. (2006). Reformasi Pendidikan sebagai Tuntutan Sejarah. INSANIA: Jurnal Pemikiran Alternatif Kependidikan, 11(2), 187-200. https://doi.org/10.24090/insania.v11i2.169

Samrin. (2016). Pendidikan karakter (sebuah pendekatan nilai). Jurnal Al-Ta'dib, 9(1), 120143. https://doi.org/10.31332/atdb.v9i1.505

Sapentri, E. (2017). Male Gaze dan Pengaruhnya Terhadap Representasi Perempuan dalam Lukisan "Realis Surealis" Karya Zaenal Arifin. Journal of Urban Society's Arts, 4(1), 29-35. https://doi.org/10.24821/jousa.v4i1.1692

Thamrin, N. H., \& Noviana, M. (2020). Pendampingan Pembuatan Mural Sebagai Upaya Perbaikan Visual Kawasan Loa Buah, Samarinda. Aksiologiya: Jurnal Pengabdian Kepada Masyarakat, 4(1), 91-99. https://doi.org/10.30651/aks.v4i1.3386

U.S, S. (2012). Arah Pendidikan di Indonesia dalam Tataran Kebijakan dan Implementasi. Formatif: Jurnal Ilmiah Pendidikan MIPA, 2(2), 111-121. https://doi.org/10.30998/formatif.v2i2.92 